DR HEATHER KAVAN is a lecturer in Massey University's Department of Communication, Journalism and Marketing.

\section{Exposing both minefields} and muddles

Media Minefield: A journalists' guide to media regulation in New Zealand, by Steven Price. Wellington: New Zealand Journalists Training Organisation, 2007, 396 pp. ISBN 0-9582058-8-4

TN READING Media Minefield, the first sentence of the book The Journalist and the Murderer kept running through my head: 'Every journalist who is not too stupid or too full of himself to notice what is going on knows that what he does is morally indefensible' (Malcolm, 1990, p. 3). The tense relationship between the media and the public is evidenced not just by complaints and lawsuits, but by the fact that juries are not usually sympathetic to journalists.

In Media Minefield, author Steven Price attempts to alleviate this problem. He doesn't go deeply into ethical debates, but cuts to the chaseadvising journalists on how to avoid

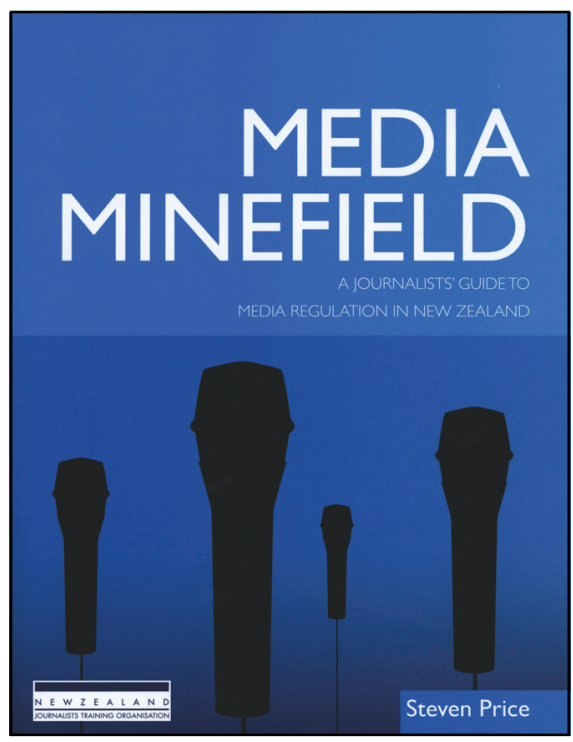

complaints and lawsuits. These, he says, 'are the bane of journalists' lives. But bad journalism is the bane of everyone else's' (p. xiii).

Hidden cameras, ambush interviews, defamation - these are a few of the issues that Price covers. The book deals primarily with decisions made by the Broadcasting Standards Authority and the Press Council. Price has carefully researched these, as his 1604 endnotes attest. He also draws on interviews with editors and news directors to provide advice on avoiding law suits and handling complaints.

The amount of work that has gone into this book is impressive. Here is a random sample of what some of the cases involve: footage of a 
person at 8am in his dressing gown putting out his rubbish; a photograph showing a car containing two dead bodies in which one of the deceased's limbs is visible; and a headline 'Go forth and fornicate' when the Pope had only been calling for more procreation in marriage.

The discussion of these issues is not particularly critical, but that is not its purpose. Media Minefield's readers will be journalists, editors, and journalism trainees for whom the book will be a useful resource. I can also imagine litigious individuals and groups rummaging through the pages to see if they have grounds for complaints.

However, anyone seeking definitive answers will be disappointed, and the author makes no promise that he can provide them. Nowhere is this better illustrated than in the section on pushiness in news gathering. Price quotes the Press Council: 'Journalists being impolite or dogged are not necessarily behaving unethically' (p. 188). Whether this means that this behaviour may not be unethical generally isn't clear, as the quotation appears to relate only to a case in which reporters were 'persistent and probably rude' in questioning an evasive official. Paradoxically, Price ends the brief section with a passing comment that 'rude and unprofessional treatment of sources by journalists may be unethical' (p. 188). So not only is the issue a minefield, it's also a muddle.

For those with a short attention span, Media Minefield won't bore you. At the book's launch, professor John Burrows, QC, reportedly described it as a 'page-turner', adding that he couldn't put the book down (Price, 2007). Part of the appeal is perhaps that many of the cases involve news items that $\mathrm{New}$ Zealanders are likely to remember. There is also Price's engaging commentary, the frequent headings, and his friendly approach.

Not withstanding the book's interesting content, I have a couple of small reservations about its style. Perhaps it's just me, but I was put off by the opening paragraphs in chapter 1 . The use of the rhetorical device anaphora was jarring - the repetition should be of the strongest, not the weakest, words in the sentence. While Price may be forgiven (he is, after all, a law lecturer, not a poet) the publisher is an organisation that claims expertise in writing.

Another discordant note is the repetition of the same cases under different headings. For example, in the chapter on privacy, a story about whether it is acceptable to give the age, gender and general location of 
a baby born to two parents who had killed people, is repeated three times. The absence of cross-referencing left me wondering if the editors had noticed the repetition.

But these are both minor issues, and I see that the book has received glowing reviews from legal experts and former journalists.

I am neither a lawyer nor a journalist, so my response to Media Minefield varies. As a researcher who sometimes writes potentially defamatory material I was hanging on to Price's every word. Some day I may need him.

As an academic who is occasionally asked by reporters for comment, I felt cautious. But as a human beingand one who wouldn't want to be filmed by a TV crew early morning in my nightclothes taking out the garbage, or photographed dead in my car with one of my limbs hanging-I felt edgy.

For me, Media Minefield is not just well researched and helpful, it is also disturbing. Perhaps that's what makes it so compelling.

\section{References}

Malcolm, J. (1990). The journalist and the murderer. London: Papermac.

Price, S. (2007). Reviews. Media law journal. Retrieved on 23 March 2008, from: www.medialawjournal. co.nz/?page_id=16
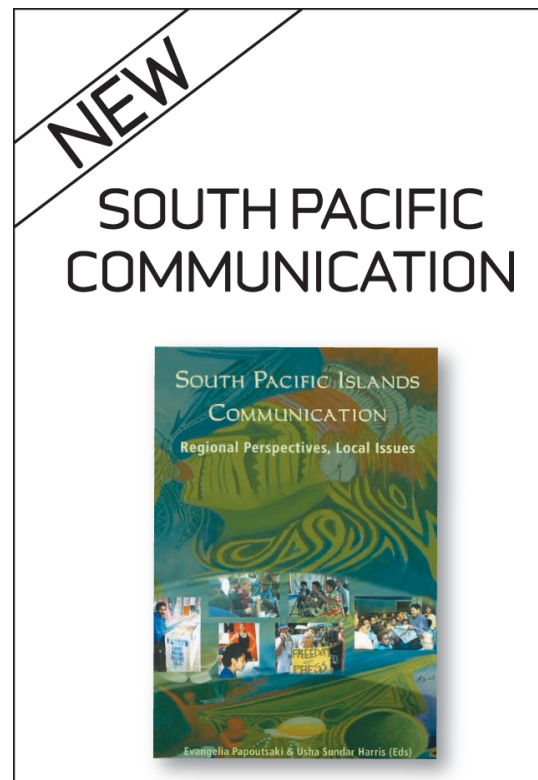

South Pacific Islands Communication: Regional Perspectives, Local Issues

Edited by Evangelia Papoutsaki and Usha Sundar Harris

Significant new scholarly contributions on communication issues by journalists and researchers working around the region.

Published by the Asian Media, Information and Communication Centre (Singapore), University of the South Pacific (Fiji) and the Pacific Media Centre.

PACIFIC MEDIA CENTRE AUT UNIVERSITY

Order from South Pacific Books Ltd www.sthpac.netstep.co.nz sales 国southpacificbooks.co.nz Content details 回:

www.pmc.aut.ac.nz/publications.html Price: NZ\$50 